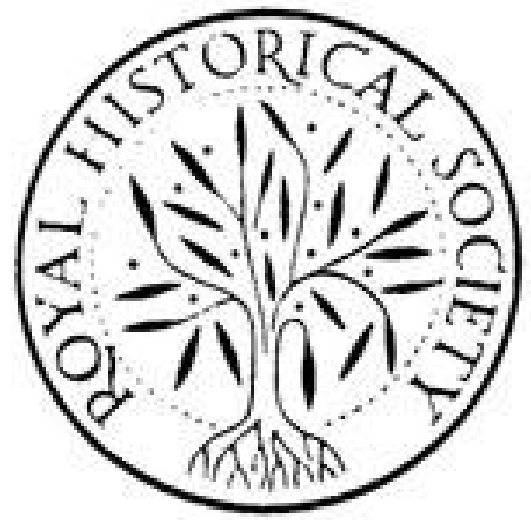

\title{
Historic Genealogy
}

Author(s): H. E. Malden

Source: Transactions of the Royal Historical Society, Vol. 4 (1889), pp. 103-123

Published by: Cambridge University Press on behalf of the Royal Historical Society Stable URL: http://www.jstor.org/stable/3678163

Accessed: 27-06-2016 05:31 UTC

Your use of the JSTOR archive indicates your acceptance of the Terms \& Conditions of Use, available at

http://about.jstor.org/terms

JSTOR is a not-for-profit service that helps scholars, researchers, and students discover, use, and build upon a wide range of content in a trusted digital archive. We use information technology and tools to increase productivity and facilitate new forms of scholarship. For more information about JSTOR, please contact support@jstor.org.

Cambridge University Press, Royal Historical Society are collaborating with JSTOR to digitize, preserve and extend access to Transactions of the Royal Historical Society 


\section{HISTORIC GENEALOGY.}

By H. E. MALDEN, M.A., F.R.Hist.S.

(Read December I887.)

I AM about to offer to the society a contribution which differs in kind from most of the papers which are read before us, and which may, I am afraid, be regarded as inferior in interest to many of them. I an conscious that I can only here touch the fringe of a very large subject, and my object is rather to put forward a claim for its further consideration than to pretend to make any adequate attempt to deal with it exhaustively now. Indeed, neither my own ability nor the patience of the audience would be equal to such an undertaking as that.

I hope, however, that in dealing with Historic Genealogy; or Genealogical History, or Scientific Genealogy, for I am uncertain by what name to best describe it, I am within the limits proposed by this society for its labours. I see that, first among the objects of the society, the promotion of the study of history on general scientific principles is mentioned. The investigation of not only the facts of history, but of the causes and motives of which the facts are an outward expression, is an all important branch of advanced historical study. Would we bring history into touch with modern political life and political and social questions of to-day, we cannot neglect any means, however unimportant or difficult they may appear in their application, which may enable us to get at the true reasons why events happened long ago. Similar reasons are influencing the present development of events around us. It, no doubt, is very hard to get at any satisfactory results; the phenomena are so complex and so 
inter-related, that it is easy to generalise too lightly and to adopt false conclusions from imperfectly acquired premises. There is the more reason not for abandoning the effort to scientifically analyse history, but rather for trying the harder to possess ourselves of all the facts before doing so. Among historic facts are the personal characters of the human actors, their nature, that which is born with them, their bodily and mental dispositions. These are to a great extent hereditary. Not only leading men, but the masses of men they lead, are worked upon to a great, though unknown, extent, by the influence of their forefathers. This consideration is often overlooked in studying or writing history, and is, therefore, also overlooked in the treatment of living political questions. I wish, therefore, to put forward a plea for scientific genealogy as being of historical and of political interest.

In the darker ages of this society it possessed a genealogical section. The genealogical information there retailed was of the ordinary unscientific character, generally speaking.

That is to say, the descent of a man or men was made out through a single line of male ancestors from some distant progenitor. So far as that was a fact, it was no doubt, in its way, a bit of useful knowledge. Many long genealogies, however, of this description have a weak point in them somewhere. A single falsification, a single confusion of names, a single hypothetical marriage, may destroy the value of the whole.

Yet these genealogies have their use when they explain the origin of claims to succession or possession actually made by some historic person, through right derived from some ancestor. They are useless, however, in enabling us to estimate the true disposition and hereditary tendencies of the person whose name stands at the end of them. His true motives and his character are not materially influenced, in most cases, by the remote ancestor whose line he carries on, or whose crown he wears.

The practice, prevailing since the most primitive ages at least, of descent of property and names in the male line, ex- 
pressed, I suppose, and perpetuates, I am sure, the belief in an exclusive or overwhelming male influence of the father upon his children. The House of Bourbon, the House of Hapsburg, the House of Anjou is spoken of as possessing certain characteristics, which, it is assumed, are handed down from a remote ancestor to his son, then to his son in turn, and so on.

I am afraid that another reason which makes us fall readily into this assumption of exclusive male influence in genealogy is that genealogies are so much easier to follow in the male line. The retention of the surname by the sons, the succession to an estate, or a title or throne, which keeps the eldest male line fixed in one place, makes it delightfully easy to run through a long pedigree of men, and to generalise upon the similarity of their characters and upon their hereditary gifts. When the daughters change their names in marriage, and when their daughters change again, it becomes harder to find out, and much harder to remember, that Mrs. Smith, who was daughter to Mrs. Brown, who was daughter to Mrs. Robinson, was descended from Mrs. Robinson's father, whose name was Jones.

No doubt, sometimes, a single ancestor, male or female, does exercise a great influence over even remote descendants. I confess that the general assumption of male influence is so general that it raises a slight presumption in favour of its partial truth. It may be the unconscious expression of an often occurring fact. But that the assumption is by no means universally true is certain. In cases of marked ability or marked weakness the exceptions are most striking.

Henry VI., for instance, showed little likeness to his father Henry V., nor to his Lancastrian or other English ancestry. The inheritance, through his mother, of the madness of Charles VI. of France, her father, is most evident.

Among the houses of which I spoke just now as possessing hereditary characteristics is that of Hapsburg. But the Hapsburgs now are not really Hapsburgs in the male line at all. Many of their ancestors were closely related, but their 
ancestress, Maria Theresa, is the main link to bind the House of Lorraine, which now rules Austria and Hungary, with their undoubtedly similar-featured ancestors of Hapsburg.

Nero had the Claudian features and disposition, but was a Claudius only in the female line, though by more than one female descent. Was Charles II., able, witty, unscrupulous, dissolute, dark and harsh-featured, more the son of the handsome, common-place, precise, industrious Charles I., who always had scruples at the wrong moment, or of Henrietta Maria, the daughter of the able, witty, and also unscrupulous and dissolute Henri IV. of France? Was the character of Henry VIII. more like that of the cautious, avaricious, and business-like Henri VII., or that of his mother's father, the pleasure-loving, reckless, and passionate Edward IV.?

Or, to take a more general instance, the great mass of the coloured population of the West Indies represents the union of white men and negro or coloured women. In their case the maternal influence is unmistakable, in character and features, even after some generations of exclusively white intermarriages.

These particular instances might be multiplied at will. There are general reasons besides for doubting the usual view. Four generations back every man has sixteen ancestors, unless their number is lessened by intermarriage of cousins. One among that group exercises but a small influence on the descendant. In the case of composite photographs it has been found that altering one component part in a group of eight has scarcely any appreciable effect upon the resulting picture. So the substitution of one ancestor for another, male or female, three generations back, will, on an average, have a very small effect upon the descendant, cases of negro or other markedly differing descent being, of course, exceptional.

It is usually safe, in the investigation of any matter, to turn to the example of those who are accustomed to make a profit in money out of dealing with similar affairs. Selfinterest, in the shape of gain of money especially, much more 
than in the shape of health, for instance, will generally guide men in the direction best suited for its attainment. In this connection it is to the point to observe that breeders of animals for profit are not bound to this theory of exclusive or excessive male influence. The breeding of cattle, sheep, and horses in particular, has been carried to a great degree of perfection in England, and will furnish us with examples.

When a great race has been run, the sporting papers do not give to the horse-breeding and horse-racing world a bare genealogy of the sire, grandsire, and so on, of the winner. The ancestry on both sides is set forth in a table showing the two parents, the four grandparents, the eight progenitors in the next generation, the sixteen in the next, and so forth. Over the more remote lines the same names continually recur-Sir Hercules, the Baron, Pochahontas, Guiccioli, and so on. The hereditary capacity of the descendant seems to depend to a great extent upon the combination of various lines of family capacity, and its special characteristics upon the constant recurrence of the same blocd.

It would be well for historians to condescend to copy this example, and to give us, so far as possible, cumulative genealogies of all the more recent ancestors of leading historical actors, rather than long drawn-out lines of descent. We should be much nearer to a true comprehension of the men and their work if this were done. The same principle should also be applied to national genealogies, only there the same exactitude would not be possible. Still something might be done to show a learner, at all events roughly, about what proportion of different races may be supposed to have entered into the ancestry of a modern people. If something be known of the capacity, as expressed in customs and institutions, of the ancestral races, something will be learnt of the more complex society of the descended people, its powers and tendencies.

But it is among individuals that the most careful observations may be made, and most striking results obtained. I must remind the society again that when I speak of results I do not mean new facts never known before at all, I merely 37 
look for a more complete understanding of known facts, a deeper insight into their causes. Family characteristics and hereditary traits of form or character are commonly accepted as existing in certain lines. A Stuart, Tudor, Bourbon, Plantagenet character is recognised. But in these and similar instances I think that an arrangement of genealogies, such as I propose, will show that the same blood is reinforced in the house by constant and repeated intermarriages, bringing each their quota of influence upon the descendants.

Let us look at the genealogy of Richard III. treated in this manner.' He is a useful example, being well known, strongly marked in character, but yet vigorously defended by some people formerly as the victim of unjust partisan depreciation. However, the good people who have gone about to whitewash his character have overlooked the inherent probability implied in his descent, that he would be a man of reckless violence and bloodshed. The crossing and recrossing of Plantagenet blood in his pedigree is most remarkable. He was descended in three lines from Edward III., in two others from Edward I., and in another from Henry III. Of course every descent from Edward III. implies descent from Isabella of France, Edward I., and Henry III. as well. These are the recurring names in his genealogy. Upon their family characteristics the history of England, France, and Scotland is a sufficient comment. With this blood he united that of the most turbulent baronial lines: Neville, Percy, Mortimer and Holland, and that of Pedro the Cruel, of Castille, who murdered his wife, his aunt, his mistress, and six of his half-brothers, and whose mother also was a murderess. Of Richard's seven nearest male ancestors, two were killed in battle and one executed as a traitor. Another, John Neville, though he died at forty-eight only, reduced eighty-three towns and castles in France; and another, Ralph Neville, passed a long life in perpetual war with the French, Scots, and his neighbours. Yet both died in their beds. Of his nearer male relatives, in

1 For a concentric genealogy of Richard III., included in that of Henry VIII. and the House of York, see the Society's Trans. vol. iii. pt. iii. p. 370. 
the three generations above him, ten died violent deaths. The number of battles fought, and murders, executions, and plots contrived by his ancestors passes counting. That they survived through such lives long enough to rear families is a proof of their fitness for their surroundings. Naturally their descendant was apt for crime, fitted to succeed in civil war, and only doing what might be prognosticated of him in cutting his way to the crown by murder, and fighting for it to the death at Bosworth.

There are other historical characters, of disputed fame, whose genealogical annals are worth looking into. Thus Henry VIII., through his mother, Elizabeth of York, shares all the above ancestry of Richard III., but two generations further removed from it. However, he strengthens the Plantagenet cross by threefold descent through his grandmother, Margaret Beaufort, from Edward III., Edward I., and Henry III. Thus, though remotely, he is descended in four lines from Edward III., three from Edward I., and two from Henry III., or in nine lines altogether from Henry III. and his father. John. The descent is remote, but there are no other strains of blood so constantly recurring in his ancestry. That he and his two sisters had eleven wives and husbands between them, and that they were grandchildren of Edward IV., and great-grandchildren of Katharine of France and Jacquetta of Luxemburg, who fell in love with their handsome attendants, may be of moment in weighing the policy of Henry VIII.'s marriages.

Again in the complete pedigree of another controverted character, Mary of Scotland, the only recurring influence is Plantagenet, of these same three kings, Edward III., Edward I., and Henry III., and she is descended from one or other of them in twelve different lines. The only other near recurring influences are the Houses of Gueldres and Luxemburg, each twice over. The former house produced one peculiarly atrocious character, Adolf of Gueldres. But if we look into her immediate ancestry, we find among her four grandparents the names of Stewart, Tudor, Guise, Bourbon de Vendôme. 
Can we ask any better guarantee for the production of intellect, courage, and defiance of morality in their descendant? Such seed being thrown into such soil as the France and Scotland of the sixteenth century.

But it is not merely single persons whose life and history may, through genealogy, be better understood. The investigation of a pedigree may reveal the reason for the decay of some ruling family, which, in its fall, involves the fate of nations, and brings about far-reaching political changes.

The tendency to the union of smaller kingdoms, duchies, or counties into large monarchies, which accompanies the progress from mediæval to modern political arrangements in Europe, has been fertile in producing such family decay. The desire for aggrandisement has led to intermarriages which have lessened the number of distinct royal houses, and a 'family policy' has led to renewed intermarriages between houses already allied, till there is much reason to believe that the limit of safety has been passed, and, in place of the reproduction of vigorcus racial characteristics, degradation and decay, even to extinction, have followed.

The history of the descendants of Ferdinand of Aragon and Isabella of Castile will, I think, be a most instructive line to follow.

The Spanish kingdoms, comparatively secluded from the rest of Europe, were often united by marriage with each other before that time. Ferdinand and Isabella were first cousins to each other, Isabella's parents were first cousins to each other, not to speak of other relationships among her and her husband's more remote ancestors. The united inheritance passed to their daughter, Juana, the mad queen. Her son, Charles, the emperor, married his first cousin, Isabella of Portugal. Their son, Philip II., married Anne of Austria, his first cousin once removed; their son, Philip III., married his second cousin, Margaret of Austria; both these latter marriages being between descendants of the mad queen Juana. Their son, Philip IV., married a daughter of Henri IV. of France, and their daughter, Anne, married the son of Henri IV. of 
Specimen of a Concentric Genealogy of Philip V. of Spain.

The persons marked with an asterisk were descended from Ferdinand and Isabella through the mad Queen Fuana.

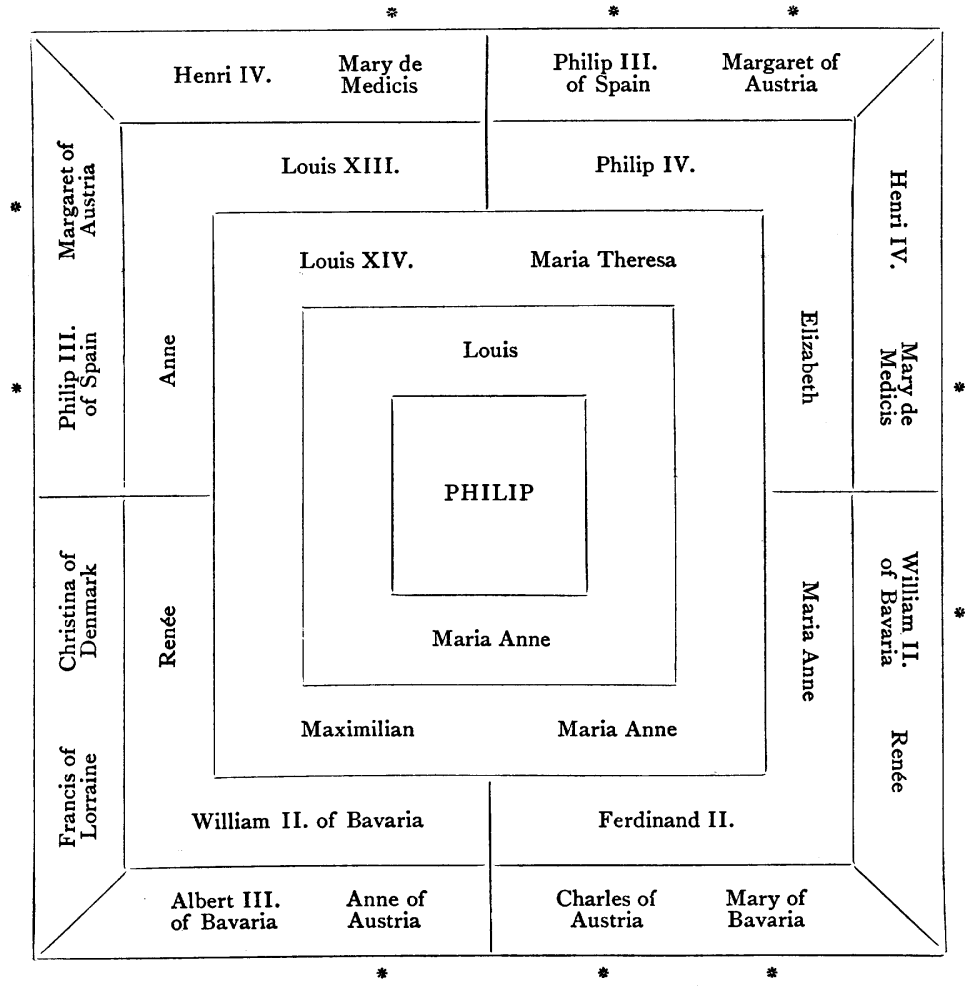


France, ${ }^{1}$ and the children of these last two marriages, double first cousins, children of two brothers and two sisters, with such a record behind them, married each other in their turn, and were the ancestors of all the later Bourbons.

This last marriage was between Louis XIV. of France and Maria Theresa of Spain, and was intended to secure the world-wide dominion of the House of Bourbon; and it was succeeded by still more intermarriages among the Houses of Bourbon, Hapsburg, and Savoy especially, bewildering in the intricate relationships which they created. Rather it did secure the continual decadence of that house in body and mind, till, of their three European thrones, their numerous duchies, and vast European and American possessions nothing remains to thern now but the throne of Spain, a power which has grown decrepit in their hands. There can be no doubt that the personal deficiencies of the members of the family have contributed in no small degree to this loss of their formerly overshadowing power, and that those personal deficiencies became marked from the time when the first inception of what was afterwards formulated as the Family Compact was made, in the fatal marriage of Louis XIV. and Maria Theresa. As I cannot expect anyone to keep these complicated genealogies clear in his memory I will try and illustrate the extraordinary interlacing of families by four examples.

When Charles II. of Spain was dying without children, three competitors were spoken of as heirs to his dominions, all descended from the mad queen Juana. Charles II. was himself descended from her in twelve different lines; Charles of Austria was descended from her in ten different lines; Philip, Duke of Anjou, was descended from her in fourteen different lines ; Joseph Ferdinand, of Bavaria, was descended from her in twenty-five different lines. These four have respectively eighteen, twenty, twenty, and sixteen ancestors in the third and fourth generations above them, instead of the

1 Mary de Medicis, wife of Henri IV., was also a great-granddaughter of Juana. 
normal twenty-four. Of course the intermarriages by no means ended with the generations of which I speak, but continued, to the ruin of the powers of the House of Bourbon.

It is true that the first Bourbon king of Spain, Philip V., a grandson of Louis XIV. and Maria Theresa, did bring with him into Spain some personal energy and some French and modern ideas, which helped to revive Spain for a time. His first marriage, however, with a cousin, Maria Louisa of Savoy, produced two sons who died without children; his son by his second wife, more distantly related to him, was Charles III., whose three successors all married cousins in turn, and reduced the Spanish monarchy, and the Sicilian monarchy, to the state in which we have seen them.

One branch of the House of Bourbon has not shared in the decay of all the others; the House of Orleans has continued to produce men worthy to be the descendants of Henry of Navarre, and the House of Orleans was not sprung originally from the fatal marriage of Louis XIV. and Maria Theresa. They have since intermarried with descendants of that line, but are not related to it so closely and repeatedly as the elder lines of the Bourbons are. The decadence of Spain and the fall of the French monarchy are, of course, to be attributed to many causes; but, considering the personal influence of the sovereigns of these countries, we may surely allow that a close study of all the ramifications of genealogy has here helped to explain historic facts.

I have chosen the genealogy of the House of Bourbon as both well known and striking in its illustration of hereditary influences, but similar decadence of royal lines from marriages dictated by policy might be cited. For instance, the German branch of the House of Austria, so long as they were connected, in policy, with their Spanish cousins, used to cement that alliance by marriages which seriously threatened the continuance of their line, which, indeed, did expire in the male line with Charles VJ. Maximilian II., who married his cousin, the sister of Philip II. of Spain, left five sons, who N.S.-VOL. IV. 
grew up and died without children. This failure of the direct line had political results. The succession passed to a collateral heir, Ferdinand II., an event which certainly aggravated the difficulties of the House of Austria at the beginning of the Thirty Years' War.

But the House of Austria had wider and more varying connections than the Bourbons, and, during the period of their great antagonism with the latter, from the War of the Spanish Succession till the end of the eighteenth century, they married into other German families, and so, perhaps, saved themselves. A more detailed examination of the various pedigrees than is here possible would show how often alliances, intended to strengthen the dynasty and increase territory, have ended in weakness or absolute extinction. An instance in ancient history will readily occur to us, when the Ptolemies of Egypt, a highly gifted dynasty to begin with, decayed and expired through still closer intermarriages than those cited above.

The matter is worthy of attention, for the union of royal persons is the only human union which is ever likely to be controlled by politic reasons, to any great extent at least ; and in the interests of the stability of states, and in the interests of the very existence of monarchy, it is as well that historic should be added to physiological arguments upon the true policy of such unions.

The lessening of the number of ruling houses in Europe, which has been going on almost uninterruptedly since the fifteenth century, and the sharp division of this diminished number into two rival religions, which often forbids their union, holds out a prospect of the possible extinction of monarchy as it now exists through the extinction of royal lines. Its extinction, I say, as it now exists, for I am inclined to believe from the universal experience of history, and from contemporary experience too, that monarchy in some form is inevitable, and corresponds to certain needs and feelings which ensure its continuance in many countries for many centuries. But, if hereditary lines die out or become impos- 
sible, the alternative monarchy is Imperialism, or a setting up of the cleverest or strongest man to be Emperor, Minister, President, or demagogue, but anyhow to be master while he stands.

Here I believe that genealogy touches actual, practical politics, besides in other ways illustrating past history.

But I should be sorry to limit the importance of genealogical study, rightly considered, even here. The race is but the family 'writ large,' and, though the questions raised are wider and more complicated, it may also be examined so as to find its prevailing blood and its hereditary peculiarities, gifts, and failings.

A national character certainly exists to some extent; a race dwelling in a certain country is one in blood. It is notorious how certain classes in narrow limits are so connected. Norfolk gentry and Lowland Scotch gentry were all more or less distant cousins to one another at one time. So the nobility of Rome were all related. The old Roman patricians, in fact, the later Roman optimates, and the Spartans too, seem to have been related beyond the point of safety, and to have dwindled.

Moreover, besides blood relationship, the members of the same race in a certain country are exposed to the influences of the same food, climate, and institutions, through centuries. How these produce a similarity like the similarity of common ancestry is, I believe, not yet fully agreed, but they do produce a likeness, as in Scotland, for instance, among people of divers descent.

It is within the function of the genealogical historian to point out the peculiarities which seem inherent in nations and their modification by foreign intermixture. Thus the capacity of the Roman aristocracy for war and for political organisation, of the Athenian citizens for literature and art, of the Scandinavians for maritime adventure, for piracy or for commerce, of the Jew for commerce, of the Teutonic nations generally for constitutional government, can hardly be doubted. The proneness of the Celtic mind to religious enthusiasm, the 
abhorrence felt by all descendants of nomads for steady labour, and many more hereditary traits might be found.

I conceive it possible that as in families marked characteristics often depend upon intermarriages of the same blood, causing it to dominate over other intermittent influences, so in races the majority may practically swamp the minority; so that though a race, like the English, may not be of absolutely pure Teutonic descent, yet the Teutonic characteristics may generally have mastered all the others.

As in the case of families, judicious or injudicious intermarriages of races may be cited, modifying their former characteristics. In England we made two most fortunate intermarriages : one with keen-witted, adventurous and organising Normans and Franks after the Norman Conquest; the second, no less important, with able and resolute religious refugees from France and Flanders, during the hundred years before and the fifty years after the Revocation of the Edict of Nantes. The revival of national energies may be explained by such intermarriages of race.

I believe, however, that the cross of the Spanish and native Indian blood in South and Central America, and of the white and black races in the West Indies, cannot be called successful in their results.

I am persuaded that the decay of institutions may also sometimes be attributed to the gradual prevalence of a strain of blood among their users different from that of those with whom the institutions grew up. Thus the republican constitution of Rome was not fitted for all the less developed peoples of Italy who tried to work it; thus the parliamentary institutions of Franks and Goths died out, as the Celtic and Iberic blood dominated over and absorbed the Teutonic in France and Spain. Thus, too, the Parliament of England, Teutonic in its origin, may not be suited to the Celts of Ireland and Wales.

I do not for a moment wish to exclude other great and complex causes as working also for such changes as these; but I am sure that a genealogical investigation of races as 
well as of men by themselves, and a study of their hereditary instincts, may both enlighten historians and instruct politicians.

I am aware that I have gone on into a subject still wider than the wide subject with which I began, yet into a province of the same field. I shall have more than fulfilled my purpose if I shall have successfully commended the subject to your notice-to traverse even part of it fully is more than I can attempt here. I shall be satisfied if $I$ have made it at all clearer how really careful and complete genealogical investigation can illustrate the natures and characters of men, and through these the events of history, and how even nations may be considered in their entirety as links in a genealogical chain. I shall in a humble way be glad if I can induce any single one of my hearers to put beside his family tree a square or circular genealogy embracing all his accessible ancestors, and concentrated upon himself or his children. If such genealogies can be inserted in history-books it will be better still.

\section{Discussion.}

Mr. Oscar Browning said that he was much interested by Mr. Malden's remarks, and that the importance of genealogy in the study of history could not be overrated. At the same time it is extremely difficult to obtain accurate information upon the subject, and in his opinion a good edition of genealogical tables published at a moderate price was very much needed.

Dr. J. Foster Palmer said that he was extremely glad of the opportunity to assist in welcoming Mr. Malden's paper as a valuable contribution to history from an anthropological standpoint, for he believed that a true basis for the study could only be secured by a due and impartial consideration of all the various sources of evidence which can be brought to bear upon it. Modern historians have relied too exclusively upon philology for the earlier, and upon documentary evidence for the later periods. Both these kinds of evidence, particularly the former, must be, and in many cases have been, corrected and modified by the researches of anthropology and archæology. There is no occasion for either class of observers to ignore or depreciate the other's work. The future progress of history depends upon the double light brought to bear upon it by the 
cultivation of the literary methods on the one hand and the scientific methods on the other.

There is much to be said in favour of Mr. Malden's plan for making genealogies more complete with a view to the study of character, both mental and physical. Many traits found in prominent individuals might often thus be traced to a more or less remote ancestor in the female line. There appeared, however, to be an assumption running through Mr. Malden's paper that, on an average, every person inherits in about equal degrees the characters of his (or her) two parents. This is by no means the case, as may be clearly shown by numerous examples from history, from physiology, and from general observation. He should be far from saying that character always comes down in a direct male line ; but there are, almost inevitably, certain influences which predominate over others, and these influences may continue to manifest themselves on the male side for many generations. This being the case, the argument from composite photographs, as employed by Mr. Francis Galton, is not only useless, but positively misleading, for it undoubtedly premises this equal division of character.

I. Physiological Deviations. - Sir Alfred Garrod, a well-known authority on 'gout,' mentions the case of a gentleman who can trace this disease in his family in a direct male line for 400 years. It came, not by reversion to an early and half-forgotten type, nor even alternately, but without a single intermission to each eldest son. It was developed too at an early age, and was not, therefore, the result of individual excesses.

Four hundred years means twelve generations. If, therefore, there exists, as is supposed, a tendency to equal division, the original gouty diathesis must in the course of 400 years have been divided by two twelve times, leaving to the present possessor the small share of $\frac{1}{40 \overline{9}}$, an amount which would be hardly discernible.

In an interesting series of papers by Dr. Douglas Lithgow recently published in the 'Provincial Medical Journal,' entitled 'From Generation to Generation,' allusion is made to a case recorded by Lancissins. It was that of a man with enlargement of the right side of the heart, whose father, grandfather, and great-grandfather suffered in precisely the same manner. Dr. Lithgow himself, as he mentions in the same article, is left-handed, a peculiarity which has descended in a direct male line for four generations. In both these cases an equal division would leave, in the last of the scries, the original tendency reduced to $\frac{1}{8}$, and therefore almost inevitably obliterated. 
2. History.-He had before alluded to the striking resemblance in character borne by Charles I. of England to his ancestor James I. of Scotland. This character passes through seven generations. An equal division, therefore, would bring it down to $\mathrm{T}_{\frac{1}{2}}$; this being modified by one intermarriage with a Stuart leaves only $\frac{1}{64}$, a subdivision of the original type which would hardly be recognisable. Yet the likeness is unmistakable. Both were enthusiastic lovers of the fine arts, industrious, refined, and domesticated, yet both were constantly in determined and fatal opposition to the most powerful of their subjects. The only fresh element in Charles I.'s character appears to be his duplicity, which he clearly inherited from Margaret Tudor, the daughter of Henry VII.

The pedigree chosen by Mr. Malden as a specimen could, he thought, be shown not altogether to corroborate his views. Admitting that the character of Richard III. might, in a general way, be synthetically produced by selections from various roots on both sides of the family tree, it appeared to him that we should arrive at a much more definite and accurate estimate if we considered it as an exact but intensified copy of his father's. All the qualities of Richard, his great talents, his military capacity, his ambition, his far-sightedness, his unscrupulousness, his hypocrisy, his disregard for human life, are seen in a more or less developed form in the character of Richard, Duke of York. On the other hand, the Neville character, which Richard ought to have inherited from his mother, is conspicuous by its absence. The Earl of Warwick, who may be looked upon as the type of the Neville family, is as far removed from Richard in character as it is possible for two men, living in the same age and under similar surroundings, to be. Warwick, although he changed his principles more than once, did so, not from ambition, but from conviction. In one instance, at least, he did so against his own interest. His springs of action were of a different class from those of Richard.

As an instance removed from all royal surroundings, the genealogy of Edmund Kean, the actor, is not without interest. Macaulay, in his 'History of England,' is at some pains to show that Kean inherited his talent from the Marquis of Halifax. This, of course, was through his mother, the daughter of George Carey. The talent of Halifax descended, there is no doubt, to his illegitimate son, Henry Carey, ${ }^{1}$ who distinguished himself both as dramatic author and musical composer. George Carey inherited in some degree his father's talent, and was also known both as writer and composer. The talent of Kean, however, was of a different order. The Careys

I Author and composer of the song, 'Sally in our Alley. 
were originative, Kean was reproductive. The talent of the actor consists in the power of receiving and reproducing impressions, and is distinct from that of the original producer. Admitting that Kean inherited a certain degree of brain-power from his mother's family, the special gifts that made him a great actor were those of receptivity and exposition, and these existed in a less developed form in at least one member of his father's family, who was well known as a mimic and ventriloquist.

3. General Observation.-Popular opinion is in many instances, as Mr. Malden admits, the expression of observed facts. In this case popular opinion, rightly or wrongly, constantly attributes certain mental and physical characteristics to certain families. Those who were acquainted with English Huguenot families would, he thought, agree with him that there is still in most instances more of the French character about them than is warranted by the small share $\left(\frac{1}{64}\right)$ which is their legitimate allowance after a residence of 200 years (six generations) in this country. The pedigree of our Norman aristocracy is, perhaps, too uncertain and remote to form a basis for accurate observation. Two of our noble families, however, are known to have come over from Holland 200 years ago with William III. The Duke of Portland he had never seen, but the Earl of Albemarle, whom he had seen several times, is almost as pure a Dutchman as his early ancestor can have been.

One of the factors which is constantly causing a deviation from the bilateral equality of inheritance is the influence which in the great majority of cases is exerted by man over woman. This, of course, is liable to exceptions, but it is nevertheless the rule that on an average a woman becomes in many important respects assimilated to her husband, and that part of this assimilated character is transmitted to their offspring. An instance of this on the physical side is seen in the well-known fact, observed and recorded by Nott ('Types of Mankind'), that a negro woman, who has once borne mulatto children to a white man, will, if afterwards married to a negro, continue to bear mulatto instead of black children. This is only one of numerous examples bearing on the same fact. Another factor not to be lost sight of is the essential difference between men and women in their modes of thought. This difference begins to manifest itself in early childhood, when boys instinctively reject those sources of amusement which occupy the minds of girls in favour of others of a more masculine character ; it continues throughout life to old age, and serves to break the continuity of certain traits of character when they descend in the female line. 
It would even appear that $\mathrm{Mr}$. Galton is hardly able to free himself from the habit of attributing some special importance to paternal descent. In his work on 'Hereditary Genius,' he condemns the celibacy of the clergy in the Roman Catholic Church on account of its depriving future generations of the influence for good which would presumably be exercised by their descendants if the priests became fathers of families. In this connection it is essential to bear in mind the fact that acquired characteristics are transmitted from generation to generation as well as inherited ones. It is a wellestablished physiological fact that new or incipient qualities may be developed by cultivation, and others may disappear from want of use. Indeed, as Ribot says, if the evolutionary theory be established, all instincts must have been acquired, and it is by accumulation through succeeding generations that they are formed and stereotyped. A familiar example of such a process affecting a nation is perhaps seen in the remarkable manner in which the word, as well as the idea of, 'duty' has fastened itself upon the minds of Englishmen. It was observed to be always the prominent idea in the dispatches of Wellington; it is known to have been so in the life of Nelson; and it has been observed by foreign writers to be constantly the prevailing thought in all assemblies of Englishmen. This result is attributed by so eminent an educational authority as Bishop Temple to the impression made by the Church Catechism on successive generations. Some such solution may perhaps be given to the problem suggested by Emerson. 'According to Tacitus,' he says, ' "the Germans were powerful only in sudden efforts, impatient of toil and labour." Such people would never have built London. I know not from which race they get their patience and tenacity, but they clinch every nail they drive.' Might not this quality too have been acquired? It was not derived from the Celts, hardly from the Danes and Normans.

The Chairman (Mr. Hyde Clarke), in proposing a vote of thanks to Mr. Malden, said the subject treated by him was of much scientific interest. In it he himself had been concerned, having treated the question of heredity when Mr. Francis Galton and himself had been regarded as holding unphilosophical doctrines. Hedissented, however, from Mr. Galton as to composite photographs. He regarded them as a fallacy, assimilating indeed to a statistical average, which was not a fact but an artificial treatment of facts. However plausible it appeared at first sight to assume $a$ priori an equal influence of the male and female parent or ancestor, practically it did not accord with what 
we could observe. Mr. Oscar Browning had very well said that William Pitt was a Grenville rather than a Pitt, but that statement would not meet the case of the elder brother, the Earl of Chatham. It was no uncommon thing to observe in a family four sons or four daughters unlike each other, but who might be traced severally to each of the four grandparents. So far from following the supposed law of equal partition of the properties of parents, there was the greatest inequality of participation and of succession. It was quite possible that properties could be manifested in this generation which had been manifested centuries ago in one ancestor. It might be that Mr. Malden's elucidation of the properties of ancestors might guide them to. the real law, always taking into due account such facts as those already cited. If a man had 16 several ancestors he would undoubtedly be in a different position from one who by accumulation had only 14 , I 2, 10, or 8. By analogy with other branches of science different combinations would be formed, for whereas the 16 ancestors would be $a, b, c, d, e, f, \& c$., those having common ancestors would form groups of $a+a, a+b, a+c, b+a, b+c$, \&c. Thus the whole physiological arrangements might be altered, just as chemical combinations are affected by the arrangements of their atoms, and in biology there was good ground for regarding with attention the combinations of male and female elements in the individual. With regard to the application of similar tests to ethnolcgical types there appeared to be a deficiency of material. It was impossible to ascertain in a tribe, as in a family, the proportion of contributory elements ; indeed, it was impossible to tell what tribes had a permanent share in the future nation, and which had merely a temporary influence. Writers were fond of supposing that the Romans in Britain, whatever they really were, had a necessary share in the ancestry of the English people. Nothing was more doubtful, for the Romans died off in battles, civil feuds, monasteries, nunneries, \&c., and became extinct in various ways. A large share had been attributed to the Celts on account of the extent of the Welsh language, yet undoubtedly we had to allow instead a larger balance to the preceding Iberian element still recognisable. On the other hand, the Norman element, chiefly that of male immigrants, appeared to have exercised and to hold to this day a much greater active influence than had been theoretically conceived. In all respects, however, it was impossible not to regret the paucity of genealogical material to which $\mathrm{Mr}$. O. Browning had pertinently referred. It was to be hoped those observations would meet with attention. The chief collections were in 
private hands, and it would be very useful if they were made available by this appeal. Although much labour had been devoted to male descent, there was, however, much on female descent, either in relation to baronies by tenure or the doctrine of female descent set up by Sir Egerton Brydges. With regard to the weight placed by Mr. Malden on the circumstances of military occupation or of death by beheading, that was rather of an accidental nature than a characteristic. 